\title{
Edukasi Sanitasi Air Bersih di Lingkungan Perumahan Daerah Rawan Banjir
}

\author{
Asri Jumadewi ${ }^{1 凶}$, Orisinal ${ }^{2}$, Herman Kurnaidi $^{3}$, Masyudi $^{4}$ \\ 1,2 Prodi D-III Keperawatan Aceh Selatan Poltekkes Kemenkes Aceh \\ ${ }^{3}$ Mahasiswa Prodi D-III Keperawatan Aceh Selatan Poltekkes Kemenkes Aceh \\ ${ }^{4}$ Fakultas Kesehatan Masyarakat Universitas Serambi Mekkah
}

Corresponding Author: asrijumadewi@poltekkeskemenkesaceh.co.id

Alamat: Jl. Merdeka no. 253 Tapaktuan Aceh Selatan

\begin{abstract}
ABSTRAK
Air merupakan salah satu komponen yang paling penting dalam kelangsungan kehidupan manusia dan makhluk hidup lainnya. Air memberikan pengaruh langsung terhadap kesehatan manusia. Air dapat menjadi media dalam penyebaran penyakit yang dikenal dengan water borne disease, tidak terkecuali air minum. Daerah rawan banjir beresiko terhadap timbulnya water borne disease terhadap berbagai penyakit, terutama penyakit berbasis lingkungan seperti diare. Pentingnya sanitasi air bersih dapat menurunkan resiko akibat bencana banjir, dengan program pengabdian kepada masyarakat melalui edukasi Kesehatan lingkungan. Edukasi ini memaparkan suatu pendidikan tentang air bersih. Kegiatan edukasi ini dilakukan di Balai Desa Carak Kecamatan Sawang Kabupaten Aceh Selatan. Metode menggunakan kuesioner pre-edukasi dan pasca-edukasi, dengan masing-masing 10 pertanyaan, diantaranya tentang sumber air bersih, ketersediaan jamban, pengelolaan sampah, saluran pembuangan air limbah (SPAL) dan drainase. Edukasi memberikan efek terhadap perubahan pengetahuan, sikap dan tindakan masyarakat tentang sanitasi air bersih, dibuktikan dari jawaban responden. Kesimpulan pengabdian masyarakat ini bahwa responden mengetahui sumber air bersih, memiliki jamban sehat, pengelolaan sampah, saluran pembuangan air limbah (SPAL) dan drainase. Saran agar dinas dan pemerintah terkait memberikan perhatian dan pengawasan terhadap daerah aliran sungai (DAS) saat volume air meningkat, dan pemeliharaan jamban desa bagi yang belum memiliki jamban sendiri.
\end{abstract}

Kata Kunci : edukasi air bersih, sanitasi lingkungan

\begin{abstract}
Water is one of the most important components in the continuity of human life and other living things. Water has a direct influence on human health. Water can be a medium for spreading a disease known as water borne disease, including drinking water. Flood-prone areas are at risk of developing water borne disease for various diseases, especially environment-based diseases such as diarrhea. The importance of clean water sanitation can reduce the risk of flood disasters, with community service programs through environmental health education. This education describes an education about clean water. This educational activity was carried out
\end{abstract}


Asri Jumadewi, dkk.

at the Carak Village Hall, Sawang District, South Aceh Regency. The method uses pre-education and post-education questionnaires, with 10 questions each, including about clean water sources, availability of latrines, waste management, sewerage and drainage. Education has an effect on changing people's knowledge, attitudes and actions about clean water sanitation, as evidenced by respondents' answers. The conclusion of this community service is that the respondents know the source of clean water, have healthy latrines, waste management, sewerage and drainage. Suggestions for related agencies and government to pay attention and control to watersheds when the volume of water increases, and maintenance of village latrines for those who do not have their own latrines.

Keywords : health education clean water, environmental sanitation

\section{PENDAHULUAN}

Definisi bencana menurut UU No. 24 tahun 2007 adalah peristiwa atau rangkaian peristiwa yang mengancam dan mengganggu kehidupan dan penghidupan masyarakat yang disebabkan baik oleh faktor alam dan atau faktor non alam maupun faktor manusia sehingga mengakibatkan timbulnya korban jiwa, kerusakan lingkungan, kerugian harta benda, dan dampak psikologis (Khasan, M., \& Widjanarko, M., 2011).

Salah satu jenis bencana alam yang sering terjadi di Indonesia adalah banjir. Banjir didefinisikan sebagai suatu keadaan sungai, dimana aliran air sungai tidak tertampung oleh palung sungai sehingga terjadi limpasan atau genangan pada lahan yang semestinya kering. Banjir disebut pula sebagai suatu keadaan aliran permukaan yang relatif tinggi dan tidak tertampung lagi oleh alur sungai atau saluran drainase (Mawardi, E., \& Sulaeman, A., 2011). Banjir sering diakibatkan oleh hujan yang terjadi selama beberapa jam. Banjir di Indonesia juga terjadi di kota-kota besar seperti Jakarta, dan sekitarnya. Bencana ini tidak dapat diantisipasi karena kekeliruan konsep drainase sejak awal (Agus R, 2009).

Beberapa penelitian yang dilakukan di daerah tropis ditemukan pola kejadian penyakit diare mengikuti pola musim. Penyakit diare yang terjadi menunjukkan puncaknya pada musim penghujan, banjir, serta kemarau juga menunjukkan adanya hubungan baru dengan kejadian penyakit diare tersebut. Penyebab utama penyakit diare yang berhubungan dengan air yang terkontaminasi seperti kolera, Crysptosporidium, Escherichia coli, Giardia, Shigella, Thyphoid, dan virus seperti hepatitis A (World Health Organization, 2003).

Air merupakan salah satu komponen yang paling penting dalam kelangsungan kehidupan manusia dan makhluk hidup lainnya. Air mempunyai kemampuan atau pengaruh langsung terhadap manusia, khususnya kesehatan manusia. Pengaruh kesehatan tersebut tergantung sekali pada kualitas air yang digunakan, dan air pun dapat berfungsi sebagai penyalur ataupun penyebar penyakit (Slamet, J. S., 2009). Air dapat menjadi media dalam penyebaran penyakit yang dikenal dengan water borne disease, tidak terkecuali air minum. Beberapa penelitian yang telah dilakukan menunjukkan bahwa diare merupakan salah satu penyakit yang disebabkan oleh kualitas air. Seperti penelitian yang dilakukan oleh Purwaningsih dan Mafazah (2013), bahwa terdapat hubungan antara ketersediaan air bersih, sarana pembuangan sampah dengan kejadian diare pada balita (Rizkiyanto M, 2014). Kurangnya cakupan air bersih 
merupakan salah satu faktor dalam kejadian penyakit diare (Singh, R.B.K., et.al., 2011).

Pentingnya penyehatan air untuk masyarakat masih menjadi isu prioritas utama di wilayah pasifik, termasuk negara Indonesia. Penyehatan air ini masuk dalam manajemen sanitasi lingkungan. Meliputi, penyehatan air bersih, ketersediaan jamban, pengelolaan sampah, pembuangan saluran pembuangan air limbah (SPAL) dan saluran drainase (daerah aliran sungai). Dengan adanya sanitasi air bersih misalnya, maka akan meningkatkan kualitas air yang digunakan, sehingga meningkat pula derajat kesehatan masyarakat (Rizkiyanto M, 2014).

Hal inilah yang mendorong peneliti untuk melakukan penyuluhan sanitasi lingkungan untuk meningkatkan pengetahuan, sikap dan tindakan masyarakat untuk berperilaku sehat. Apalagi daerah rawan banjir membutuhkan pengetahuan, sikap dan tindakan yang benar dalam mempertahankan kesehatan. Perilaku kebersihan yang buruk serta air minum yang tidak aman berkontribusi terhadap 88 persen kematian anak akibat diare di seluruh dunia, bahkan terhadap penyakit lainnya. Bagi anak-anak yang bertahan hidup, seringnya menderita diare dapat berdampak terhadap masalah gizi, sehingga menghalangi anak-anak untuk dapat mencapai potensi maksimal mereka. Kondisi ini selanjutnya menimbulkan implikasi serius terhadap kualitas sumber daya manusia dan kemampuan produktif suatu bangsa di masa yang akan dating (Unicef, 2012).

Masyarakat sekitar masih menggunakan air sungai untuk memenuhi kebutuhan mandi, cuci dan kakus. Namun, untuk kebutuhan konsumsi mereka menggunakan air PAM desa yang dikelola oleh masyarakat sekitar. Namun sebagian besar menggunakan air sumur untuk konsumsi. Beberapa desa di kecamatan Sawang tergolong rawan banjir akibat kurang baiknya daerah aliran sungai (DAS), adanya galian C yang rawan longsor serta berkurangnya tanaman hijau disekitar pegunungan tersebut. Kemungkinan-kemungkinan air masyarakat akan tercemar dengan air banjir, sehingga diperlukan pengetahuan tentang sanitasi agar dapat terhindar dari kejadian penyakit akibat banjir. Hal ini sesuai dengan studi Indonesia Sanitation Sector Development Program (ISSDP) tahun 2006, menunjukkan $47 \%$ masyarakat masih berperilaku buang air besar ke sungai, sawah, kolam, kebun dan tempat terbuka (DepKes RI, 2014).

Asumsi penulis bahwa masih kurangnya kesadaran masyarakat untuk peduli terhadap kesehatan lingkungan menyebabkan penulis merasa perlu melakukan diseminasi informasi berupa edukasi mengenai pengetahuan tentang sanitasi lingkungan agar diharapkan kesehatan masyarakat meningkat. Berdasarkan penelitian yang telah dilakukan oleh Khoiran (2015) bahwa pengelolaan sanitasi lingkungan pemukiman yang baik mampu memberikan dorongan pemberdayaan masyarakat untuk mengatasi permasalahan rawan banjir dan kemungkinan terhindar dari berbagai kejadian penyakit akibat banjir (Khoiron dan Dewi R, 2015).

\section{METODE}

Sasaran dari kegiatan pengabdian masyarakat ini adalah ibu rumah tangga yang hadir dan bersedia sebagai partisipan, dengan jumlah 25 orang. Metode pengabdian yang dilakukan dengan pemberian informasi tentang air bersih dan persyaratannya. Informasi diberikan dengan menggunakan metode ceramah dan demonstrasi. Kuesioner diberikan sebelum dilakukan penyuluhan untuk menilai pengetahuan awal partisipan 
Asri Jumadewi, dkk.

dan diakhir penyuluhan untuk menilai efektifitas edukasi dalam perolehan pengetahuan partisipan. Penyuluhan menggunakan alat bantu visual (Microsoft Powerpoint) disertai demonstrasi jenis air yang layak dikonsumsi, panduan berupa leaflet dilaminasi setiap lembarnya sehingga tahan lama dan partisipan dapat membawa pulang leaflet tersebut untuk referensi cepat di rumah. Kegiatan dilaksanakan pada hari Rabu, tanggal 18 September 2019. Lokasi pengabdian ini dilaksanakan di desa Mutiara, Kecamatan Sawang, Kabupaten Aceh Selatan Tapaktuan.

Rancangan Evaluasi yang digunakan:

1. Penyuluhan: tentang air bersih yang layak dikonsumsi dan digunakan untuk aktivitas sehari-hari dan kemungkinan resiko yang ditimbulkan bagi kesehatan akibat banjir.

2. Melakukan demonstrasi/memperagakan jenis-jenis air yang Nampak bersih tapi tidak layak dikonsumsi.

3. Post Test (pasca-penyuluhan) kepada partisipan dan didampingi oleh tim pengabmas.

4. Penilaian hasil pre test dan post test, dengan mempersentasekan jumlah keseluruhan dari setiap jawaban 10 pertanyan di dalam kuesioner. Sehingga dapat digambarkan besaran persentase setiap pertanyaan dan dibandingkan dengan pasca penyuluhan.

\section{HASIL}

Gambaran distribusi responden pra-penyuluhan, menunjukkan bahwa sebagian besar responden setuju bahwa air bersih adalah air yang jernih, tidak berasa, tidak berbau dan tidak (48,00\%), harus dimasak dahulu sebelum dikonsumsi $(56,00 \%)$, namun membolehkan sampah dan buang air besar di sungai $(32,00 \%)$, memiliki saluran pembuangan air limbah (44,00\%). Namun, responden tidak menyetujui kepemilikan jamban sehat (wc) berleher angsa dan ada septitanknya $(32,00 \%)$, tidak setuju mengelola sampah RT $(48,00 \%)$ dan tidak menjadi keharusan menguras sumur jika air banjir sampai masuk $(48,00 \%)$. Sedangkan untuk pertanyaan jarak sumur gali dengan septictank adalah $10 \mathrm{~m}$, partisipan menjawab tidak tahu $(64,00 \%)$ dan tidak mengetahui bahwa banjir dapat menularkan penyakit seperti diare $(52,00 \%)$.

\section{PEMBAHASAN}

Gambaran pengetahuan partisipan umumnya belum mengetahui sanitasi air bersih secara benar, berdasarkan jawaban responden [Tabel 1]. Responden juga belum mengetahui bahwa air dapat menjadi media dalam penyebaran penyakit seperti diare.

Evaluasi efektifitas penyuluhan dilakukan dengan memberikan kuesioner pascapenyuluhan [Tabel 2]. Pasca-penyuluhan terjadi perubahan respon partisipan yang menunjukkan perolehan pengetahuan mengenai sanitasi air bersih yang benar. Pengetahuan yang diberikan melalui edukasi ini bahwa, air yang jernih, tidak berasa dan tidak berwarna merupakan air yang layak digunakan, selain itu air memiliki parameter kimiawi dalam Peraturan Menteri Kesehatan Republik Indonesia Nomor 492/MENKES/PER/IV/2010 tentang persyaratan air minum.

Memiliki jamban sendiri dengan saluran pembuangannya menjadikan limbah tidak mengalir ke sembarang tempat yang akan menjadi sumber penyakit, sehingga tidak mencemari sungai. Perhatian terhadap sanitasi air dapat mencegah berbagai penyakit dan menjadikan lingkungan tetap sehat. Banjir kerap terjadi akibat ulah 
manusia yang membuang sampah ke sungai, hal ini mengakibatkan pendangkalan dan daerah aliran sungai menyempit maka jika terjadi curah hujan tinggi air tidak lagi tertampung dan akan meluap sehingga banjir. Sebagaimana dinyatakan bahwa sanitasi air bersih akan meningkatkan kualitas air yang digunakan, sehingga meningkat pula derajat kesehatan masyarakat (Rizkiyanto M, 2014). Daerah-daerah yang tidak memiliki system drainase yang baik dapat terkena banjir. Selokan yang tertutup oleh timbunan sampah merupakan salah satu contoh system drainase yang tidak baik (Slamet, J. S., 2009). Hal lain disebabkan penggundulan hutan di sepanjang sungai sehingga air tak lagi terserap namun meluap dan dapat merusak rumah-rumah penduduk bahkan korban jiwa (Anonimous, 2019).

Perubahan pengetahuan dan sikap responden tersebut, didapatkan setelah pengisian kuesioner pasca-penyuluhan. Semua jenis perilaku kesehatan bernilai baik bagi jaminan kesehatan, bila kita perhatikan selalu dikaitkan dengan konsep pencegahan menghindari penyakit (konsep fivelevel ofpreventition against deseases oleh leavel and clark) yang melahirkan istilah Health Prevention Behaviour. Perilaku kesehatan seseorang biasanya memiliki kecenderungan dipengaruhi oleh kepercayaan. Karenanya, mengubah perilaku kesehatan yang semula nonmedis melalui pendidikan kesehatan harus didahului oleh konsep knowledge-attitude-practice (Ryadi, 2016). Sehingga, responden dapat berpengetahuan baik terhadap sanitasi air bersih, hal ini disebabkan adanya perilaku dan gejala perilaku yang tampak pada kegiatan seseorang dipengaruhi oleh faktor genetik dan lingkungan (Notoatmodjo, S. 2011).

Menurut konsep H.L.Blum, bahwa perubahan perilaku setelah pendidikan kesehatan dalam masyarakat dapat berhasil jika disertai dengan dukungan promosi kesehatan, yang meliputi intervensi melalui predisposing, enabling dan reinforcing determinant $^{11}$. Sehingga, penyuluhan kesehatan ini dilakukan untuk mendukung pengetahuan dan sikap lebih baik terhadap sanitasi air bersih bagi daerah rawan banjir.

\section{KESIMPULAN}

Kesimpulan dari edukasi sanitasi air bersih daerah rawan banjir adalah sebagai berikut:

1. Pre-edukasi bahwa responden sudah mengetahui syarat air bersih, adanya SPAL dan drainase, namun tidak mengetahui syarat jamban sehat, penyakit akibat banjir (diare), dan pengelolaan sampah.

2. Pasca-edukasi terjadi perubahan perilaku responden tentang syarat jamban sehat, penyakit akibat banjir (diare), dan pengelolaan sampah.

3. Edukasi yang dilakukan berhasil memodifikasi pengetahuan partisipan mengenai sanitasi air bersih dan risiko penyakit akibat banjir terkait dengan penyehatan/sanitasi lingkungan.

\section{DAFTAR PUSTAKA}

Agus R, 2009, Bahaya Banjir dan Cara Penanggulangannya, Jakarta: Bengawan Ilmu.

Anonimous, 2019. Badan Nasional Penanggulangan Bencana, http://www.geospasial.bnpb.go.id diakses tanggal 10 Maret 2019. 
Asri Jumadewi, dkk.

DepKes RI, 2014, Profil Kesehatan Indonesia Tahun 2014, Jakarta: Departemen Kesehatan Republik Indonesia.

Khasan, M., \& Widjanarko, M., 2011, Perilaku Coping Masyarakat Mengahadapi Banjir, Jurnal Psikologi Pitutur, Vol 1 No. 2.

Khoiron dan Dewi R, 2015, perilaku masyarakat dalam pengelolaan sanitasi lingkungan pemukiman di perkebunan kopi kabupaten jember:fakultas kesehatan masyarakat universitas jember.

Mawardi, E., \& Sulaeman, A., 2011, Partisipasi Masyarakat dalam Pengurangan Resiko Bencana Banjir, Surakarta: Pusat Penelitian dan Pengembangan Sumber Daya Air.

Notoatmodjo, S. 2011. Ilmu Kesehatan Masyarakat. Rineke Cipta, Jakarta

Ryadi, 2016, Ilmu Kesehatan Masyarakat. Jakarta

Rizkiyanto M, 2014, Pengaruh Ketersediaan Sarana Sanitasi Dasar dan Status Rawan Banjir Terhadap Kejadian Diare, skripsi Ilmu Kesehatan Masyarakat Universitas Negeri Semarang.

Singh, R.B.K., Hales, S., Wet, N.D., Raj, R., Heamden, M., \& Weinstein, P., 2011, The Influence of Climate Variation and Change in Diarrheal Disease in the Pacific Islands, Environmental Health Perspectives, 109, 155-159.

Slamet, J. S., 2009, Kesehatan Lingkungan, Yogyakarta: UGM Press

Unicef, 2012, Ringkasan Kajian Air Bersih, Sanitasi dan Kebersihan. https://www.unicef.org/indonesia/id/A8B_Ringkasan_Kajian_Air_Bersih.pdf diakses pada tanggal 25 Maret 2019.

World Health Organization, 2003, climate change and Human Health Risks and Responses, Ganeva: Author.

\section{LAMPIRAN}

Tabel 1. Distribusi respon pra-penyuluhan $(n=25)$

\begin{tabular}{|c|l|c|c|c|c|c|c|}
\hline \multirow{2}{*}{ No Pertanyaan } & \multicolumn{5}{|c|}{ Jawaban } \\
\cline { 4 - 8 } & \multicolumn{1}{|c|}{ SS } & S & TT & TS & STS & A \\
\hline & $\begin{array}{l}\text { Air bersih adalah air yang jernih, tidak berasa, tidak } \\
\text { berbau dan tidak berwarna }\end{array}$ & 24,00 & 48,00 & 8,00 & 4,00 & 0,00 & 16,00 \\
\hline 2 & Air dimasak dahulu sebelum diminum & 40,00 & 56,00 & 0,00 & 4,00 & 0,00 & 0,00 \\
\hline 3 & $\begin{array}{l}\text { Memiliki jamban sehat (wc) dengan leher angsa dan } \\
\text { ada septic tanknya }\end{array}$ & 8,00 & 28,00 & 8,00 & 32,00 & 12,00 & 12,00 \\
\hline 4 & Sampah dan buang air besar boleh di sungai? & 0,00 & 32,00 & 20,00 & 24,00 & 12,00 & 12,00 \\
\hline 5 & $\begin{array}{l}\text { Saluran pembuangan air limbah RT bapak/ibu } \\
\text { memiliki saluran sendiri }\end{array}$ & 12,00 & 44,00 & 20,00 & 12,00 & 0,00 & 12,00 \\
\hline 6 & $\begin{array}{l}\text { Bagaimana tindakan bapak/ibu jika ada air tergenang } \\
\text { disekitar perumahan (baiknya dilancarkan } \\
\text { alirannya=drainase) }\end{array}$ & 60,00 & 40,00 & 0,00 & 0,00 & 0,00 & 0,00 \\
\hline 7 & Sumur gali berjarak 10 m dengan septic tank & 0,00 & 8,00 & 64,00 & 8,00 & 0,00 & 20,00 \\
\hline 8 & $\begin{array}{l}\text { Banjir dapat menyebabkan penyakit berbasis } \\
\text { lingkungan (seperti diare) }\end{array}$ & 0,00 & 12,00 & 52,00 & 0,00 & 0,00 & 36,00 \\
\hline 9 & $\begin{array}{l}\text { Pengelolaan sampah RT baiknya dibakar atau } \\
\text { compossing }\end{array}$ & 4,00 & 40,00 & 0,00 & 48,00 & 4,00 & 4,00 \\
\hline 10 & $\begin{array}{l}\text { Suatu keharusan menguras sumur jika air banjir } \\
\text { sampai masuk ke dalam air sumur }\end{array}$ & 8,00 & 40,00 & 4,00 & 48,00 & 0,00 & 0,00 \\
\hline
\end{tabular}

Keterangan : SS (Sangat Setuju); S (Setuju); TT (Tidak Tahu); TS (Tidak Setuju); STS (Sangat Tidak Setuju); A (Tidak Mengisi) 
BAKTIMAS

Vol. 3, No. 1,

eISSN 2685-113x

Jurnal Pengabdian pada Masyarakat

Maret 2021

pISSN 2685-0303

Tabel 2. Distribusi respon pasca-penyuluhan $(n=25)$

\begin{tabular}{|c|c|c|c|c|c|c|c|}
\hline \multirow[b]{2}{*}{ No } & \multirow[b]{2}{*}{ Pertanyaan } & \multicolumn{6}{|c|}{ Jawaban } \\
\hline & & $\mathbf{S S}$ & $\mathbf{S}$ & TT & TS & STS & $\mathbf{A}$ \\
\hline 1 & $\begin{array}{l}\text { Air bersih adalah air yang jernih, tidak } \\
\text { berasa, tidak berbau dan tidak berwarna }\end{array}$ & 80,00 & 20,00 & 0,00 & 0,00 & 0,00 & 0,00 \\
\hline 2 & Air dimasak dahulu sebelum diminum & 84,00 & 16,00 & 0,00 & 0,00 & 0,00 & 0,00 \\
\hline 3 & $\begin{array}{l}\text { Memiliki jamban sehat (wc) dengan leher } \\
\text { angsa dan ada septic tanknya }\end{array}$ & 32,00 & 68,00 & 0,00 & 0,00 & 0,00 & 0,00 \\
\hline 4 & Sampah dan buang air besar boleh di sungai? & 0,00 & 0,00 & 0,00 & 80,00 & 20,00 & 0,00 \\
\hline 5 & $\begin{array}{l}\text { Saluran pembuangan air limbah RT bapak/ibu } \\
\text { memiliki saluran sendiri }\end{array}$ & 32,00 & 68,00 & 0,00 & 0,00 & 0,00 & 0,00 \\
\hline 6 & $\begin{array}{l}\text { Bagaimana tindakan bapak/ibu jika ada air } \\
\text { tergenang disekitar perumahan (baiknya } \\
\text { dilancarkan alirannya=drainase) }\end{array}$ & 60,00 & 40,00 & 0,00 & 0,00 & 0,00 & 0,00 \\
\hline 7 & Sumur gali berjarak $10 \mathrm{~m}$ dengan septic tank & 24,00 & 76,00 & 0,00 & 0,00 & 0,00 & 0,00 \\
\hline 8 & $\begin{array}{l}\text { Banjir dapat menyebabkan penyakit berbasis } \\
\text { lingkungan (seperti diare) }\end{array}$ & 28,00 & 72,00 & 0,00 & 0,00 & 0,00 & 0,00 \\
\hline 9 & $\begin{array}{l}\text { Pengelolaan sampah RT baiknya dibakar atau } \\
\text { compossing }\end{array}$ & 20,00 & 80,00 & 0,00 & 0,00 & 0,00 & 0,00 \\
\hline 10 & $\begin{array}{l}\text { Suatu keharusan menguras sumur jika air } \\
\text { banjir sampai masuk ke dalam air sumur }\end{array}$ & 8,00 & 92,00 & 0,00 & 0,00 & 0,00 & 0,00 \\
\hline
\end{tabular}

Keterangan : S S (Sangat Setuju); S (Setuju); TT (Tidak Tahu); TS (Tidak Setuju);

STS (Sangat Tidak Setuju); A (Tidak Mengisi). 